\title{
Record of the genus Lycopodites in the Lower Permian of Paraná Basin, Brazil
}

\author{
JULIANA SALVI ${ }^{1}$, ANDRÉ JASPER ${ }^{1}$, FRESIA RICARDI-BRANCO ${ }^{2}$, \\ MARY ELIZABETH C. BERNARDES-DE-OLIVEIRA ${ }^{3}$ and MARGOT GUERRA-SOMMER ${ }^{4}$ \\ ${ }^{1}$ Setor de Botânica e Paleobotânica do Museu de Ciências Naturais da UNIVATES (UNIVATES), \\ Programa de Pós-Graduação em Ambiente e Desenvolvimento, Rua Avelino Tallini, 171, \\ Bairro Universitário, 95900-000 Lajeado, RS, Brasil \\ ${ }^{2}$ Instituto de Geociências, Universidade Estadual de Campinas (UNICAMP), \\ Caixa Postal 6152, 13083-970 Campinas, SP, Brasil \\ ${ }^{3}$ Instituto de Geociências da Universidade de São Paulo (USP), Universidade de Guarulhos (UnG), \\ Centro de Ciências Exatas e Tecnológicas, Laboratório de Geociências, Praça Tereza Cristina, 1, \\ Centro, 07023-070 Guarulhos, SP, Brasil \\ ${ }^{4}$ Instituto de Geociências da Universidade Federal do Rio Grande do Sul (UFRGS), Avenida Bento Gonçalves, 9500, \\ Agronomia, 91509-900 Porto Alegre, RS, Brasil \\ Manuscript received on April 24, 2007; accepted for publication on March 25, 2008; \\ presented by ALCIDES N. SIAL
}

\begin{abstract}
The genus Lycopodites, which encompasses the herbaceous forms of the lycopsids, presents broad time and spacial distribution during the Paleozoic in the Northern Hemisphere, with its initial records dating from the European Devonian. As to Gondwanan Paleozoic, to this moment, only Lycopodites amazonica Dolianiti had been reported for the Amazonian Middle Devonian (Curuá Group). Thus, the specimens reported in this study such as Lycopodites sp., coming from sedimentary rocks of the Itararé Subgroup, São Paulo State, and Lycopodites riograndensis sp. nov., collected in Rio Bonito Formation, Rio Grande do Sul, represent the oldest fertile forms recorded for Gondwana and the first ones to be described for the Paraná Basin. Its presence in layers, deposited after the end of the Neopaleozoic Glaciation, shows the appearance of new taxa in high latitudes, as well as the diversity of the lycopsids present in the Basin, previously indicated through the abundance of spores associated to the Class Lycopsida present in the palinomorphous assemblages.
\end{abstract}

Key words: Lycopodites sp., Lycopodites riograndensis sp. nov., Gondwana, Lower Permian, Paraná Basin.

\section{INTRODUCTION}

The main purpose of this paper is to describe specimens of herbaceous lycopsids found in Permian sediments of the Brazilian portion of Paraná Basin, and to present an overview of this genus for the Paleozoic period in this basin. Although the lycopsids are little representative in the present floras, they are meaningful herbaceous and arborescent elements of Paleozoic associations (Jasper

Correspondence to: Juliana Salvi

E-mail: jusalvi@univates.br/sbp_mcn@univates.br and Guerra-Sommer 1998). These plants arose in the Devonian, reaching their apex in the Upper Carboniferous, and started to decline from the Permo-Triassic limit on; from the end of the Meso-Cenozoic they are restrict registered, with only the herbaceous forms left. According to Mussa (2000), these plants are important elements in the Carboniferous Basins of the Northern Hemispheres and in the Permian coal systems distributed through several basins of the Gondwana. 
In the Paraná Basin following lycopsids genera are registered: Brasilodendron, Bumbudendron, Leptophloeum and Lycopodiopsis (Chaloner et al. 1979, Jasper and Guerra-Sommer 1998, Alarcon and Bernardes-de-Oliveira 1999, Ricardi-Branco and Torres 2003) all with arbustive habit; nevertheless, herbaceous lycopsids have not been previously mentioned for this area.

The material used in this study comes from two outcrops. The oldest one is associated to the Itararé Subgroup and is known as Sítio Itapema Outcrop, located in the Municipality of Cerquilho, State of São Paulo, Brazil (Fig. 1) (Rocha-Campos et al. 2000). The other one is Quitéria Outcrop, located in the Municipality of Encruzilhada do Sul, State of Rio Grande do Sul, Brazil (Fig. 1), which is related to the Rio Bonito Formation.

\section{GEOLOGICAL FRAMEWORK}

The Cerquilho area is stratigraphically located in the upper sedimentary sequence of the Itararé Subgroup or in the basal portion of the Tietê/Rio Bonito Formation, in the Tubarão Group. The lithostratigraphic position of the area is still a matter of dispute. Rohn (1987), Fúlfaro et al. (1991), among other authors, have considered this area as belonging to the postglacial Tietê Formation, correlated with the Rio Bonito Formation of Southern Brazil states. On the other hand, Nagali and Consoni (1987), Martini and Rocha-Campos (1991), Santos et al. (1996), RochaCampos et al. (2000) among others, have considered the Cerquilho coal measures as a result of an interglacial environment, included in the Itararé Subgroup. Some elements from this taphoflora were studied by Dolianiti and Millan (1973), Millan (1977, 1991, 1995), Millan and Dolianiti (1977, 1979, 1980a, b, 1981, 1982), Iannuzzi and Rohn (1995), Ricardi-Branco et al. (1999), Bernardes-de-Oliveira et al. (1999), Rohn and Lages (2000), Martins Neto et al. (1999, 2000) and RicardiBranco and Bernardes-de-Oliveira (2000). These elements are the following: sphenopsids, Cordaitales, protoglossopterids (?) and abundant seeds - Cornucarpus cerquilhensis, Samaropsis rigbyi, Samaropsis dolianitii and Samaropsis tietensis. The appearance of the first elements of the Glossopteris Flora in the Paraná Basin was recorded in this outcrop. It is considered AsselianSakmarian in age due to its palynological content, which is characterized by basal Protohaploxypinus goraiensis Subzone of the Vittatina constabilis Interval Zone (Souza and Marques-Toigo 2003, Souza 2006).

According to Jasper et al. (2006), Quitéria Outcrop is an isolated and fragmented exposition of the Rio Bonito Formation over the Sul Rio-Grandense Shield, preserved in a collapsed block following the North-West direction. The outcropping section is little thick $(6.40 \mathrm{~m})$ and does not present contact with the overlapped and eroded interval, neither with the one underlying, which is covered. The profile of the site can be divided into two clearly distinguished intervals: a basal one, with large incidence of organic matter, and an upper one, with incidence of plant megafossils, but with little, nearly unpreserved, organic matter. Thus, the lower level of the upper depositional interval corresponds to a roof level, with records of a unique megaflora, constituted by fragments (Jasper et al. 2006) of conifers, fronds of filicopsids, Pteridospermales and rare Glossopteridales. Based on palynoassemblages, Jasper et al. (2006) confirm that the interval of the Quitéria Outcrop is related to the upper part of the Vittatina costabilis Zone, described by Souza and Marques-Toigo (2003), conferring a Kungurian age for deposition of the analyzed sediments.

\section{MATERIALS AND METHODS}

The fossil material collected at the Sítio Itapema Outcrop corresponds to impressions found in a light-brown siltite overlying carbonaceous bed. The whole sedimentary sequence lies within a coarse-grained sandstone. The studied specimens integrate a collection of more than 200 samples collected by several researchers during two decades, and now part of the Scientific Collection of the Laboratory of Systematic Paleontology of the Geosciences Institute of São Paulo University.

At the Quitéria Outcrop the specimens of herbaceous lycopsids impressions were collected from a yellowish $45 \mathrm{~cm}$ thick thin sandstone layer, in which it could also be seen the impressions of Coricladus quiteriensis, Botrychiopsis valida, contra-molds and molds of stem bases of Brasilodendron pedroanum, as well as impressions of Glossopteridales leaves. These specimens are stored in the Botanic and Paleobotanic Sector of the UNIVATES Natural Science Museum under the initials $\mathrm{PbU}$. 


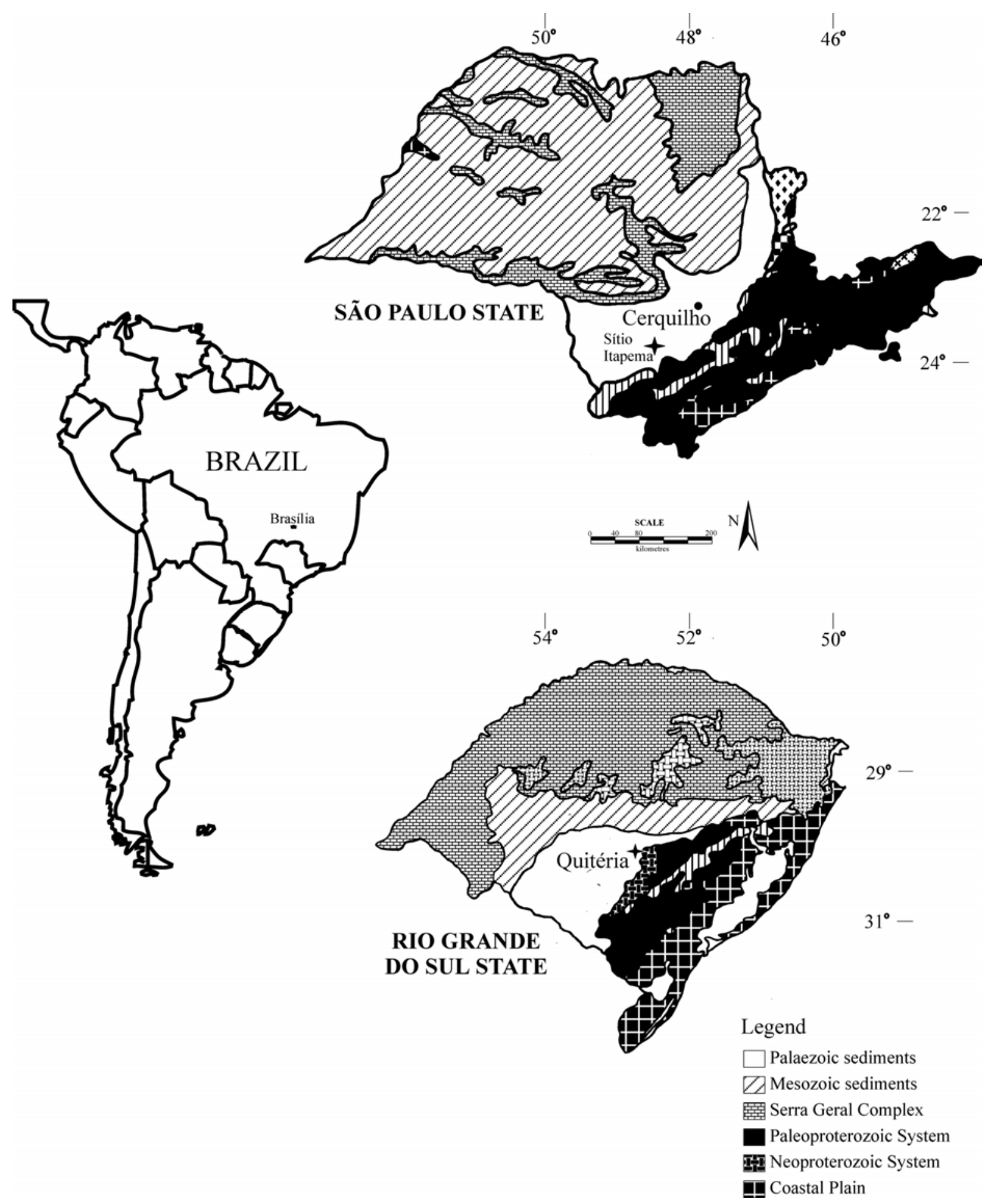

Fig. 1 - Localization of the studied areas: Cerquilho and the Sítio Itapema Outcrop, in the São Paulo State; Quiteria Outcrop, in the Rio Grande do Sul State. 
All the specimens corresponding to herbaceous lycopsids were analyzed with the use of a stereoscopic microscope, photographed and drawn with the light camera resource, and measures were recorded, such as the width and length of branches, microphylls, sporangia and stems. Observations made with the stereoscopic microscope indicate that there has not been preservation of cuticles and spores.

\section{TAXONOMIC EVALUATION}

The systematic classification of fossil plants, used in this study is the one used by Stewart and Rothwell (1993), who used cladistic methods for including fossil forms in the taxonomic groups of fossil and modern plants.

\section{Realm Plantae \\ Division Trachaeophyta \\ Class Lycopsida \\ Order Lycopodiales \\ Family Lycopodiaceae}

The family Lycopodiaceae includes land herbaceous plants and epiphytes approximately $5-20 \mathrm{~cm}$ high presenting dichotomous branching and simple leaves (microphylls) 0.2-2 cm long (Judd et al. 2002). According to Raven et al. (2003) in this family are included the modern genera Lycopodium, Phylloglossum, Huperzia, Phlegmariurus, among others, adding up to approximately 15 tropical and 7 temperate zone genera (United States and Canada).

According to Chaloner (1967), the fossil record of this family is scarce, represented by the herbaceous genus Lycopodites Lindley and Hutton (1833). This genus resembles the modern Lycopodium (Doubinger et al. 1995). The generic name Lycopodites was used for the first time to describe some third order stems densely covered by small foliar cushions which, later on were described as conifer fragments (Taylor and Taylor 1993). In more recent descriptions this genus includes stems or axes organized in a helicoid arrangement and, if presenting sporangia in the adaxial side of the leaves, they were isolated or organized in strobiles. Specimens of Lycopodites have been described as important elements from Devonian deposits (Boureau 1967), remaining actual systems, including isophyllous and anisophyllous forms (Taylor and Taylor 1993).
Genus Lycopodites Lindley and Hutton 1833

Lycopodites sp.

(Fig. 2)

Specimen: GP/3T 2276

Provenance: Sítio Itapema, Cerquilho, São Paulo State, Brazil.

Stratigraphical level: Upper portion of Itararé Subgroup or lower portion of Tiete Formation.

Age: Early Permian/Asselian-Sakmarian.

\section{DESCRIPTION}

Impression of delicate stem fragment, presented in two discontinuous portions caused by fragmentation upon specimen collection, belonging to the same axes. Its total length is $45.0 \mathrm{~mm}$ and it is $2.5 \mathrm{~mm}$ wide. It presents lepidodendroid phyllotaxy, scars in the foliar basis not clearly outlined, fusiform, with $2.5 \mathrm{~mm}$ of length by $1.0 \mathrm{~mm}$ of width, with acute inferior and superior ends. The scar of the circular vascular bundle is little clear. No evidences of ligule or parichnos. Falcate uninerved microphylls, arranged helicoidally, connected to the stem through a wide swollen base with $2.0 \mathrm{~mm}$ of width; their laminar portion is aciculated and do not present preserved apex, and it is $2.0 \mathrm{~mm}$ long and $0.5 \mathrm{~mm}$ wide. They emerge from the stem at $45^{\circ}$. It presents sparse sporophylls between the sterile microphylls, bearing ovate pedicellate sporangia of axillary position. Rounded sporangia with approximately $0.6 \mathrm{~mm}$ diameter, supported by $0.4 \mathrm{~mm}$ long pedicels.

\section{COMPARISON AND DISCUSSION}

Although it has not been possible to verify the homospory due to the poor preservation of the specimen, the supposed absence of ligule, the presence of uninerved microphylls and most importantly, the presence of sporangia on the axils of sporophylls similar to vegetative microphylls and scattered among them enable a reasonably safe identification of this specimen as belonging to the genus Lycopodites Lindley and Hutton 1833.

The specimen GP/3T - 2276 resembles the specimen Lycopodites sahnii Lele apud Surange (1966: 15, Fig. 6), originated in the Triassic of South Rewa 

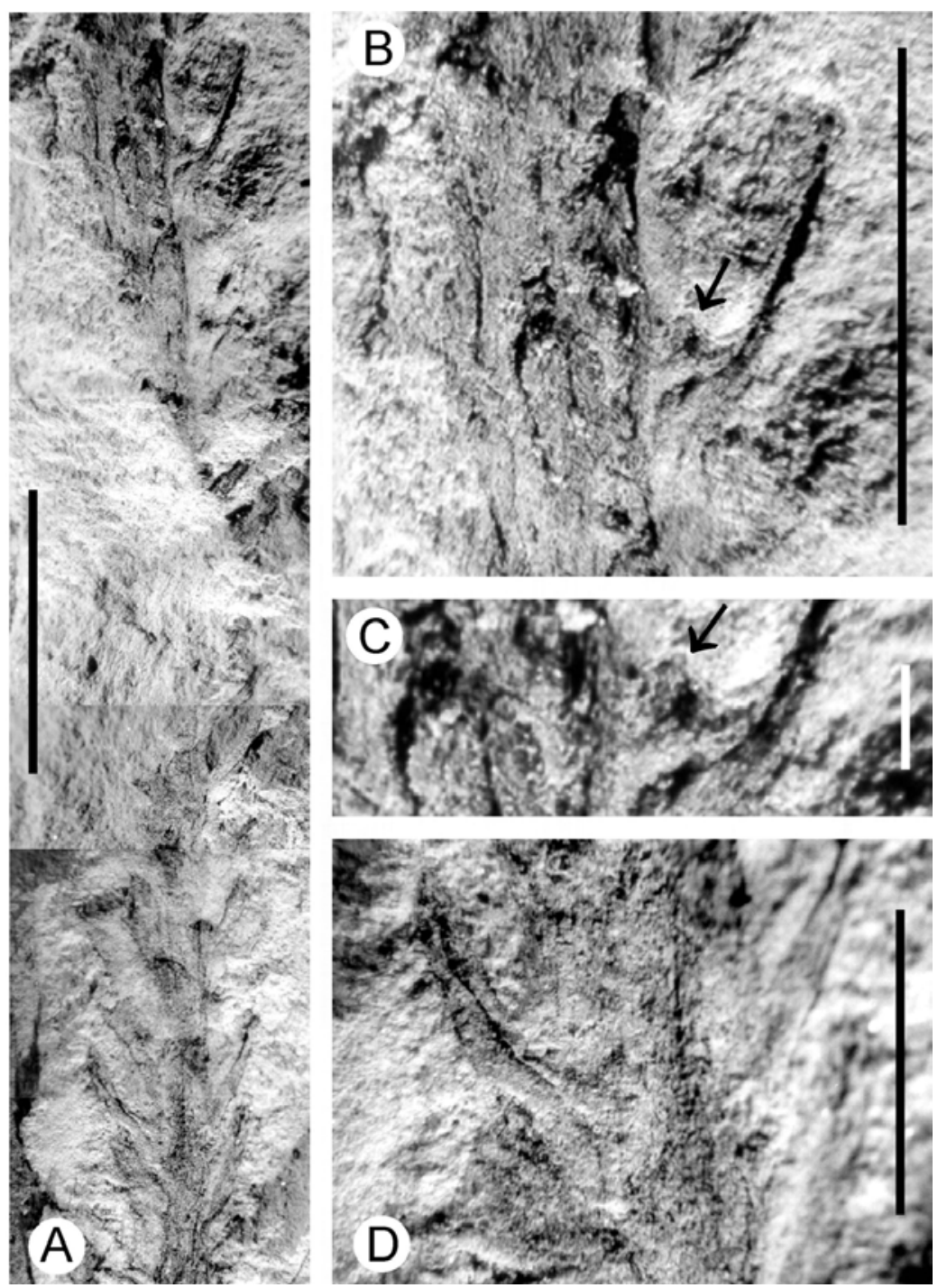

Fig. 2 - Lycopodites sp.: A) General view of the availed material (GP/3T 2276 - graphic scale corresponding to 10.0 mm); B) Detail of the apical portion of Fig. 2A, demonstrating a microphyll attached to the stem and pointing the presence of sporangia (graphic scale corresponding to $10.0 \mathrm{~mm}$ ); C) Detail pointing the sporangia of Fig. 2B (graphic scale corresponding to $1.0 \mathrm{~mm}$ ); D) Detail of a sterile microphyll with incurved basis and a central nervure (graphic scale corresponding to $5.0 \mathrm{~mm}$ ).

Gondwana Basin, India, concerning the following characteristics: dimensions, shape of the scars in the foliar base, and helicoidal arrangement of the scars. It differs in the following: emergence angles of $45^{\circ}$ in the Brazilian specimen, whereas the Indian presents $90^{\circ}$ angles; the width and the swollen shape of the microphyll base and the presence of pedicellate axillary sporangia in the Brazilian specimen.

The specimen studied differentiates itself from all the fertile species of the genus Lycopodites recorded by Chaloner (1967). As for the species based solely on vegetative bodies presenting isophyllia, Lycopodites carbonaceous Feistmantel 1875, from the Upper Carboniferous of Czech Republic and other European sites, would be the closest representative. Nonetheless, its microphylls of contracted base are quite distinct from those, with the swollen base of the specimen from São Paulo; furthermore, the lack of description of reproduc- 
tive parts and dimensions prevents us from making a more accurate comparison. The specimen studied is distinct from Lycopodites riograndensis sp. nov. once the sporangia it presents are pedicellate and smaller.

The studied specimen also differs from Lycopodites amazonica described by Dolianti (1967) for the Amazonian Basin (Devonian - Curuá Group) once the latter presents an extremely thin (approximately $1.00 \mathrm{~mm}$ ) and stiff stem with erect linear leaves; these are apparently stiff, forming a $55^{\circ}$ angle, arranged in a pseudo-spiral way that does not resemble at all the slightly flexous stems with falcate and decurrent leaves typical of the specimens of Lycopodites Lindley and Hutton, 1833 (non Brongniart). Due to the above it was decided to classify the studied specimen as "sp.", and wait for more specimens, which could then allow a safer identification.

\section{Genus Lycopodites Lindley and Hutton Lycopodites riograndensis sp. nov.} (Fig. 3)

Holotype: PbU 190 (displayed in the Paleobotanic Collection of the Botanic and Paleobotanic Sector of the UNIVATES Natural Science Museum).

Paratypes: PbU 033, 038, 294, 262, 427.

Name derivation: specific epithet derived from the name of the State of Rio Grande do Sul, location of this species occurrence.

Provenance: Quitéria Outcrop, Encruzilhada do Sul, State of Rio Grande do Sul, Brazil.

Statigraphical level: Rio Bonito Formation, Lower Permian, Paraná Basin.

Age: Early Permian/Kungurian

\section{DESCRIPTION}

The studied material consists of vascular plants branch fragment of lepidodendroid phyllotaxy, preserved as impressions (Fig. 3). Their total length varies from 6.82 to $46.22 \mathrm{~mm}$ and their width, from 4.81 to $12.48 \mathrm{~mm}$; their stems are between 0.73 to $2.28 \mathrm{~mm}$ wide.

Its stem is densely covered by uninerved microphylls, rounded at their base, occasionally tapering gradually towards the apex (Fig. 3) or keeping their rounded shape to the end (Fig. 3). These microphylls vary between $0.63-5.84 \mathrm{~mm}$ in length, and $0.25-1.37 \mathrm{~mm}$ in width, and are arranged helicoidally along the stem, emerging from the thallus at $45^{\circ}$ (Fig. 3). Neither foliar scars nor ligules are preserved.

Some specimens present sporangia with ovateelliptical shape, with measures varying from 0.78 $3.21 \mathrm{~mm}$ in length and $0.09-1.47 \mathrm{~mm}$ in width, distributed among the microphylls, developing in the adaxial faces and emerging from the axils.

\section{COMPARISON AND DISCUSSION}

A difficulty found when studying fossils of the Lycopodites type is distinguishing these remains from distal branches of the species of the order Lepidodendrales. However, when there is the presence of sporangia distributed longitudinally along the stem, in association with leaves, as is the case with the material here studied, this distinction is clear. The absence of the ligule is another aspect to be used to distinguish the two groups. Furthermore, there are some species of Lycopodites with strobiles, that are also found in some species of microsporangiate Lepidostrobus which can, in fact, represent an herbaceous coned Lycopodium plant (Taylor and Taylor 1993).

Nevertheless, the specimens found in Quiteria Outcrop can be clearly included in the genus Lycopodites for presenting stems densely covered with microphylls with helicoidal distribution, having ovate-helicoidal sporangia clearly preserved in the basal portions of the adaxial faces of the microphylls (Taylor and Taylor 1993).

Another comparison that could be made is with Oxroadia gracilis, that, according to Taylor and Taylor (1993) is a small lycopsid dichotomically branched without clear preservation of the foliar cushion, but that presents the bases of the decurrent leaves. Nevertheless, the description of this genus made by Lindley and Hutton (1833) is based on specimens of the Lower Carboniferous (Calciferous Sandstone Series, Scotland). The microphylls do not present ligule and are vascularized by a single bundle. The sporangia are elongated and formed on sporophylls whose apex is turned downward. Nothing is known about the spores. This genus is considered as an herbaceous lycopsid, unlike 

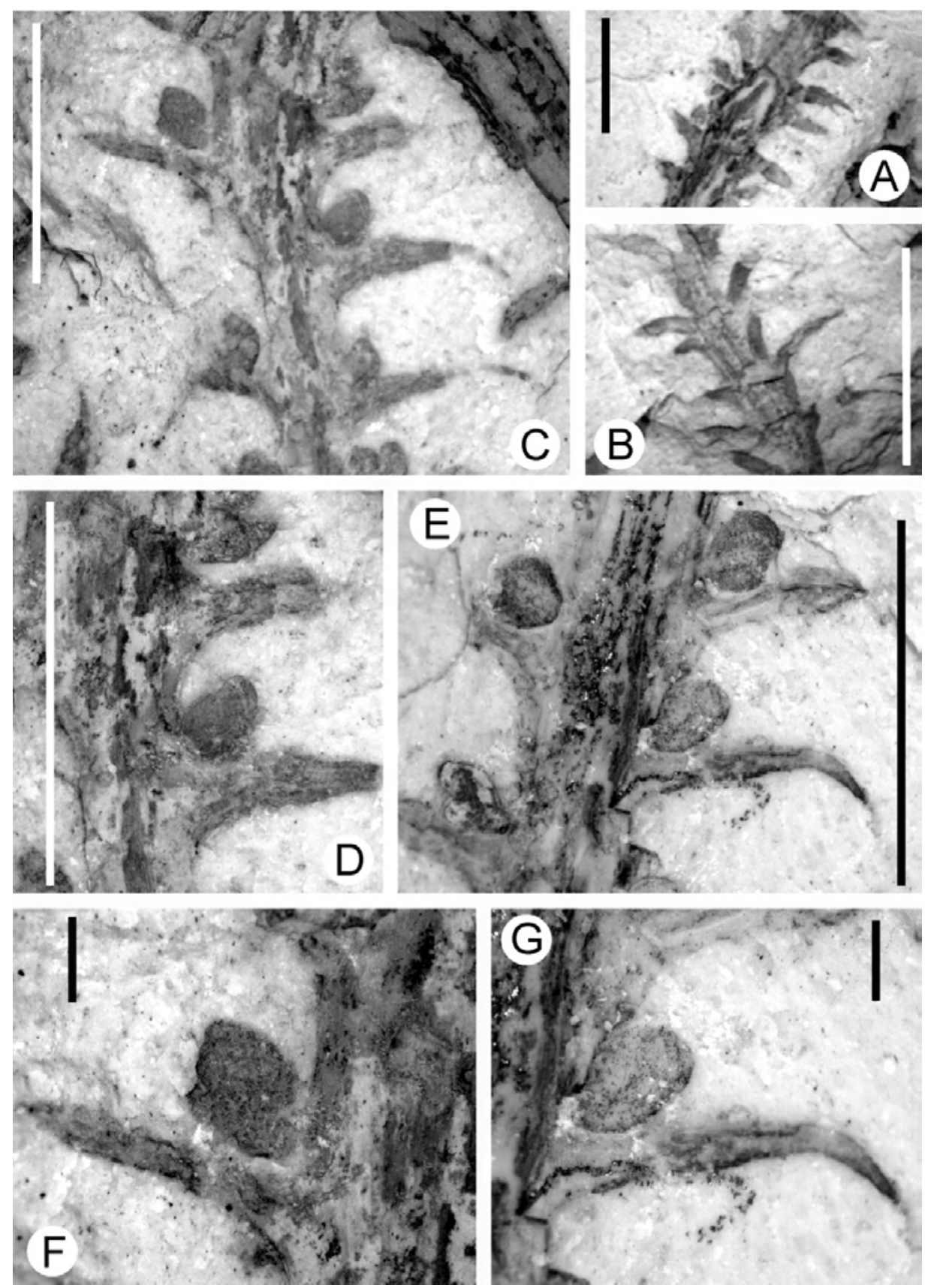

Fig. 3 - Lycopodites riograndensis: A) General view of the availed material (PbU 038 - graphic scale corresponding to $10.0 \mathrm{~mm}$ ); B) Detail of the round form microphylls from the basal to the apical portion ( $\mathrm{PbU} 262$ - graphic scale corresponding to $10.0 \mathrm{~mm}$ ); C) Detail of the basal round form and the apical sharp form of the microphyles ( $\mathrm{PbU} 190$ - graphic scale corresponding to $5.0 \mathrm{~mm}$ ); D) Detail of the Fig. 3C with the distribution of sporangia at the right side (graphic scale corresponding to $5.0 \mathrm{~mm}$ ); E) Detail of helicoidal distribution of the microphylls at the stem with attached sporangia (PbU 190 - graphic scale corresponding to $5.0 \mathrm{~mm}$ ); F) Detail of Fig. 3C demonstrating a sporangia at the left side (PbU 190 - graphic scale corresponding to $1.0 \mathrm{~mm}$ ); G) Detail of Fig. 3E demonstrating a sporangia at the right side (PbU 190 - graphic scale corresponding to $1.0 \mathrm{~mm}$ ). 
the distal branches of the arborescent form, due to the absence of secondary tissues in the vascular system and cortex. However, the specimens analyzed here do not present evidence of dichotomy nor decurrence of the foliar bases, but do present ovate-elliptical sporangia in the adaxial faces of the non-curved sporophylls.

Synlycostrobus tyrmensis is also an interesting lycopsid of the end of the Jurassic and beginning of the Cretaceous of Siberia that has an uncommon cone arrangement (Taylor and Taylor 1993). It is thought to have been a crawling plant, probably not very different from the modern Lycopodium. The ligulate leaves are isophyllous. The cones emerge from what have been called fertile shoots, each of them located at the axis of the leave or bract. The cones are small (5.0 mm long) and consist of approximately 20 sporophylls helicoidally arranged. Each sporophyll has a conspicuous distal blade and an end leaning downward. Superficially, the fertile branches of the Synlycostrobus resemble primary axes and smaller shoots (cones) which characterize the Cordaitales. Although the morphological characteristics suggest proximity with the taxon, the presence of the ligule in the Synlycostrobus dismisses this correlation.

Thus, the specimens here studied, originating from the Quiteria Outcrop, can be clearly classified as belonging to genus Lycopodites. However, all its unique characteristics prevent us from relating it with species of it or of other genera of herbaceous lycopsids of the Permian, which justifies the creation of a specific name. Therefore, it is proposed the creation of the specific epithet "riograndensis" to this new species of the genus Lycopodites, resulting in the name Lycopodites riograndensis.

\section{FINAL REMARKS}

The apparent absence of the ligule, the presence of uninerved microphylls and mainly, the presence of sporophylls with axillary sporangia similar to vegetative mycrophylls scattered among them allow a relatively safe identification both from the Itapema Outcrop (Itararé Subgroup) and the Quitéria Outcrop (Rio Bonito Formation) within the genus Lycopodites.

Regarding the distribution of the genus Lycopodites (Fig. 4) and its presence in the Paraná Basin, some comments can be made. Records of this genus begin in
Europe with Boureau (1967), mentioning Lycopodites in the Devonian of Czech Republic and Germany, Carboniferous of Scotland, France and England, as well as Upper Carboniferous in Northern America. The other occurrences in the Northern Hemisphere are related to the Mesozoic. In Gondwana, all occurrences of Lycopodites already recorded, with the exception of Lycopodites amazonica, described by Dolianiti (1967), for Devonian, are associated, according to Chaloner (1967), to the Mesozoic (Lycopodites gracilis and Lycopodites sahnii in India's Triassic; Lycopodites aberi in New Zealand's Jurassic and Lycopodites victoriae in Australia's Jurassic). Thus, the forms here described for Paraná Basin are the oldest fertile structures of this genus recorded for the Southern Hemisphere.

The records of microspore and megaspore species is abundant for the Neopaleozoic of Paraná Basin; many of them are associated to lycopsids (eg. Sublagenicula, Punctatisporistes, Foveosporites, Lundbladispora, Densosporites, Cirratriradites, Kraeuselisporites, Vallatisporites and Cristatisporites). Thus, in biostratigraphic zonings proposed for this basin in paleopalynologic studies (Ricardi-Branco et al. 2002, Amaral and Ricardi-Branco 2004, Souza and Marques-Toigo 2003, Souza 2006), the presence of lycopsids spores becomes a relevant aspect, although it is not known its kinship with the genera of the stems of lycopsids described for the basin. The occurrence of the lycopsids, mainly the ones with arbustive habit (Brasilodendron, Bumbudendron, Leptophloeum and Lycopodiopsis, Chaloner et al. 1979, Jasper and Guerra-Sommer 1998, 1999, Alarcon et al. 1999, Ricardi-Branco et al. 2002), and now herbaceous, is frequent in swampy sites associated to the generation of coal levels and/or strata. This continuous presence of lycopsids, from the Carboniferous to the end of the Permian in vegetable fossil assemblages, supports the hypothesis that the Paraná Basin was inhabited by this group since the oldest records of Carboniferous (Pennsylvanian; Souza et al. 2006) to the newest in the Permian (Rohn 1997). This distribution and their reaching the western southern Gondwana might have happened firstly with the Northern Hemisphere lycophytes; this possibility is also suggested by Piérart (1962, 1975, 1981, 1984) for some megaspore species such as Sublagenicula brasiliensis, that can be considered 


\begin{tabular}{|c|c|c|c|c|c|c|c|c|}
\hline \multirow{2}{*}{\multicolumn{2}{|c|}{ Time }} & \multirow{3}{*}{ Species } & \multicolumn{6}{|c|}{ Geographic Distribution } \\
\hline & & & \multirow{2}{*}{$\begin{array}{l}\text { Central } \\
\text { Europe }\end{array}$} & \multirow{2}{*}{$\begin{array}{l}\text { Ocidental } \\
\text { Europe }\end{array}$} & \multirow{2}{*}{$\begin{array}{c}\text { North } \\
\text { America }\end{array}$} & \multirow{2}{*}{$\begin{array}{c}\text { South } \\
\text { America }\end{array}$} & \multirow{2}{*}{ India } & \multirow{2}{*}{$\begin{array}{l}\text { Australia \& } \\
\text { New Zeland }\end{array}$} \\
\hline Era & Period & & & & & & & \\
\hline Cenozoic & $\begin{array}{c}\text { Quaternary } \\
\text { Tertiary }\end{array}$ & & & & & & & \\
\hline \multirow{3}{*}{ Mesozoic } & Cretaceous & $\begin{array}{l}\text { L. cretaceum } \\
\text { L. marylandica } \\
\text { L. teilhardi } \\
\text { L. dichotoma } \\
\end{array}$ & $\mathbf{x}$ & $\mathbf{x}$ & $\begin{array}{l}\mathbf{X} \\
\mathbf{X}\end{array}$ & & & \\
\hline & Jurassic & $\begin{array}{l}\text { L. sewardi } \\
\text { L. arberi } \\
\text { L. victoriae } \\
\end{array}$ & & $\overline{\mathbf{X}}$ & & & & $\begin{array}{l}\mathbf{X} \\
\mathbf{X} \\
\end{array}$ \\
\hline & Triassic & \begin{tabular}{|l|} 
L. scanicus \\
L. sahnii \\
L. gracilis \\
\end{tabular} & & $\overline{\bar{X}}$ & & & $\begin{array}{l}\mathbf{X} \\
\mathbf{X}\end{array}$ & \\
\hline \multirow{3}{*}{ Paleozoic } & Permian & \begin{tabular}{|l} 
L. sp. \\
L. riograndensis
\end{tabular} & & & & $\begin{array}{l}\bar{X} \\
x \\
\end{array}$ & & \\
\hline & $\begin{array}{l}\text { Carboni- } \\
\text { ferous }\end{array}$ & $\begin{array}{l}\text { L. pendulus } \\
\text { L. meeki } \\
\text { L. carbonaceous } \\
\text { L. zeilleri } \\
\text { L. denticulatus } \\
\text { L. macrophyllous } \\
\text { L. leptostachys } \\
\text { L. stockii } \\
\end{array}$ & $\begin{array}{l}\mathbf{X} \\
\mathbf{X}\end{array}$ & $\begin{array}{l}\mathbf{X} \\
\mathbf{X} \\
\mathbf{X} \\
\mathbf{X} \\
\mathbf{X} \\
\mathbf{X} \\
\mathbf{X} \\
\end{array}$ & $\begin{array}{l}X \\
X\end{array}$ & & & \\
\hline & Devonian & \begin{tabular}{|l|} 
L. amazonica (?) \\
L. oosensis \\
L. hostimensis
\end{tabular} & $\begin{array}{l}\mathbf{X} \\
\mathbf{X} \\
\end{array}$ & & & $\overline{\bar{X}}$ & & \\
\hline
\end{tabular}

Fig. 4 -Distribution of the genus Lycopodites during the time.

transgressive megaspores that migrated during the Carboniferous from regions near the limits of glaciation to regions that subsequently would be taken by the Glossopteris Flora.

\section{ACKNOWLEDGMENTS}

The authors are grateful to Biol. MSc. Cátia Viviane Gonçalves for her collaboration in the final edition of the figures. The authors also wish to acknowledge the financial support granted to this research by Fundação de Amparo à Pesquisa do Estado de São Paulo (FAPESP), through Project N. 97/03639-8: "Survey of the Upper Carboniferous - Lower Permian (Tubarão Group) Paleofloristic Composition and Succession in the State of São Paulo"; Fundação de Amparo à Pesquisa do Estado do Rio Grande do Sul (FAPERGS) and Conselho Nacional de Desenvolvimento e Tecnologia (CNPq).

\section{RESUMO}

O gênero Lycopodites, que engloba formas herbáceas de licópsidas, apresenta ampla distribuição temporal e espacial durante o Paleozóico no Hemisfério Norte, iniciando seu registro no Devoniano da Europa. Já no Paleozóico do Gondwana, até o presente momento, somente Lycopodites amazonica Dolianiti havia sido reportada para o Devoniano Médio da Amazônia (Grupo Curuá). Assim, os exemplares reportados no presente trabalho como Lycopodites sp., provenientes de rochas sedimentares do Subgrupo Itararé, SP, e Lycopodites riograndensis sp. nov., coletados na Formação Rio Bonito, RS, representam as formas férteis mais antigas registradas para o Gondwana e as primeiras a serem descritas para a Bacia do Paraná. A sua presença em camadas depositadas após o término da glaciação neopaleozóica, evidencia o ingresso de novos taxa em latitudes altas, bem como a diversidade das licópsidas presentes na Bacia, já esboçada através dos abundantes esporos associados à Classe Lycopsida presentes nas assembléias de palinomorfos.

Palavras-chave: Lycopodites sp., Lycopodites riograndensis sp. nov., Gondwana, Permiano Inferior, Bacia do Paraná.

\section{REFERENCES}

Alarcon CM and Bernardes-De-Oliveira MEC. 1999. Neopaleozoic Lycophyta in the Paraná Basin (Brazil). I - General stratigraphical evaluation, with emphasis on Lycopodiopsis derbyi Renault. Rev Un Guar 4: 35-49.

AmARAL PGC AND RicARdi-BRANCO F. 2004. Ocorrência de megásporos no Carbonífero Superior (Subgrupo Itararé) na porção NE (Estado de São Paulo) da Bacia do Paraná, Brasil. Rev Bras Geo 34: 253-262. 
Bernardes-De-Oliveira MEC, Rohn R, Souza PA, RicARDi-BRANCO F, RÖSLER O, IANNUZZI R AND ZAMPIROLli AP. 1999. Revision of Upper Paleozoic phytobiostratigraphy schemes in the northern portion of Paraná Basin, Brazil. In: InTERnATIONAL Congress on CARboniferous Permian, 14, Abstracts, Calgary, $12 \mathrm{p}$.

Boureau E. 1967. Traité de Paleobotanique, Tome II: Bryopyta, Psilophyta, Lycophyta. Masson et Cie (Eds), Paris, $845 \mathrm{p}$.

Chaloner W. 1967. Lycophyta. In: Boureau E (Ed), Traité de Paleobotanique. Tome II. Bryophyta, Psilophyta et Licophyta. Masson et Cie Editeurs. Paris, p. 437-802.

Chaloner WG, Leistikow KU And Hill A. 1979. Brasilodendron gen. nov. and B. pedroanum (Carruthers) comb. nov., a Permian lycopod from Brazil. Rev Palaeobot Palyn 28: 117-136.

Dolianiti E. 1967. Uma licopodiacea do Devoniano do Amazonas. In: Simpósio Sobre A BIOTA AMAzÔNICA, 1, Atas, Belém: CNPq, p. 141-144.

Dolianiti E and Millan JH. 1973. Novo afloramento de vegetais gondwânicos no Estado de São Paulo. An Acad Bras Cienc 45: 653-654.

Doubinger J, Vetter P, Langiaux J, Galtier J And Broutin J. 1995. La flore fossile du Basin houiller de Saint-Étienne. Tome 164 Paléobotanique. Paris: Mémoires du Muséum d'Historie Naturelle. 357 p.

Fúlfaro VJ, Perinotto AJ and Barcelos JH. 1991. Formação Tietê: o pósglacial no Estado de São Paulo. In: Simpósio de Geologia do Sudeste, 2, Atas, São Paulo, SBG, p. 397-404.

IANNUZZI R AND ROHN R. 1995. Discussão sobre a presença do gênero Glossopteris na tafoflora Cerquilho (Grupo Tubarão, Bacia do Paraná, Estado de São Paulo) e seu possível significado biocronoestratigráfico. In: CONGRESSO Brasileiro de Paleontologia, 14, Atas, Uberaba, p. 62-63.

JASPer A AND Guerra-Sommer M. 1998. Licófitas cormofíticas arborescentes do Afloramento Quitéria - Formação Rio Bonito (Bacia do Paraná), RS. Rev Pesq 25: 43-60.

Jasper A ANd Guerra-Sommer M. 1999. Licófitas arborescentes in situ como elementos importantes na definição de modelos deposicionais (Formação Rio Bonito Bacia do Paraná - Brasil). Rev Pesq 26: 49-58.

Jasper A, Menegat R, Guerra-Sommer M, CazzuloKLEPZIG M And Souza PA. 2006. Depositional cyclicity and paleoecological variability in Quitéria outcrop Rio Bonito Formation, Paraná basin, Brazil. J. South Amer Earth Scienc 21(3/4): 276-293.
Judd WS, Campell CS, Kellogg EA and Stevens PF. 2002. Plant Systematics - A Phylogenetic Aproach. Sinauer Associaties Inc. Publishers. Massachussets, 464 p.

MARTINi P AND RochA-CAMPOS AC. 1991. Interglacial and early post-glacial, Lower Gondwana coal sequences in the Paraná Basin, Brazil. In: International GondWANA Symposium, 7, Proceedings. São Paulo: IGUSP/FAPESP, p. 317-336.

Martins-Neto RG, Bernardes-de-Oliveira MEC, RiCARDI-BRANCO F AND RÖSleR O. 1999. Primeiro registro de Grylloblatida (Insecta, Pinideliidae), associado à tafoflora de Cerquilho, Paleozóico Superior da bacia do Paraná, Brasil. In: Reunião AnUal da Sociedade Brasileira de Paleontologia, 1, Guarulhos: UnGNSP/SBP, $10 \mathrm{p}$.

Martins-Neto R, Bernardes-De-Oliveira MEC, RÖSLER O, RICARDi-BRANCO F, WeINSZHULtz F AND Perinotto JA. 2000. New Grylloblattidea (Insecta) from the Paraná Basin. Carboniferous Southeast, Brazil. In: International MEeting on PALEOARTHRopodology, 1, Abstract, Ribeirão Preto:USP/RP, $33 \mathrm{p}$.

Millan JH. 1977. Sementes platispérmicas do Eogondwana, São Paulo (Bacia do Paraná). An Acad Bras Cienc 49: 581-595.

Millan JH. 1991. Novas ocorrências de sementes platispérmicas nos municípios de Itapeva, SP e Cerquilho, SP em tafofloras do Grupo Tubarão, Eogondwana da Bacia do Paraná. An Acad Bras Cienc 63: 96.

Millan JH. 1995. Novas ocorrências de sementes platispérmicas em tafofloras associadas a camadas carbonosas do Grupo Tubarão, Eogondwana da Bacia do Paraná, no Estado de São Paulo. An Acad Bras Cienc 67: 117-128.

Millan JH and Dolianiti E. 1977. Esfenófitas do Eogondwana de Cerquilho, São Paulo (Bacia do Paraná). 1 Gênero Paracalamites. An Acad Bras Cienc 49: 469-477.

Millan JH and Dolianiti E. 1979. Esfenófitas do Eogondwana de Cerquilho, São Paulo (Bacia do Paraná). 3 - Gênero Phyllotheca. Bol Asoc Latinoamer Paleobot Palinol 6: 1-4.

Millan JH And Dolianiti E. 1980a. Esfenófitas do Eogondwana de Cerquilho, São Paulo (Bacia do Paraná), Brasil. 2 - Gênero Stephanophyllites. In: CONGRESO Argentino de Paleontología y BioestratigráFia, 2, Congreso LatinoAmericano de PALEONTOlogía, 1, Actas, Buenos Aires, Argentina 4: 113-127.

Millan JH And Dolianiti E. 1980b. Sobre um novo "fertiliger" no Eogondwana de Cerquilho, São Paulo (Bacia do Paraná), Brasil. In: Congreso Argentino De PALeontología y Bioestratigráfia, 2, Congreso 
Latinoamericano de Paleontología, 1, Actas, Buenos Aires, Argentina. 4: 128-134.

Millan JH and Dolianiti E. 1981. Cordaitales do Eogondwana de Cerquilho, São Paulo (Bacia do Paraná). An Acad Bras Cienc 53: 807-815.

Millan JH AND Dolianiti E. 1982. Sobre a presença de Rubidgea no Eogondwana de Cerquilho, Subgrupo Itararé de São Paulo. Bol IG-USP 13: 56-65.

Mussa D. 2000. Paleobotânica. In: CARvalho IS (Ed), Paleontologia. Rio de Janeiro: Interciência, p. 231-326.

Nagali JT And Consoni JOC. 1987. Comportamento faciológico do intervalo que encerra as camadas de carvão na região de Cerquilho. In: CONGRESSO BRASILEIRO DE Geologia, 32, Anais, Rio de Janeiro: SBG 2: 914-982.

PIÉRART P. 1962. Distribution stratigraphique et géographique des mégaspores du Paleózoique. Pollen et Spores 4: 370 .

PIÉRART P. 1975. Systématique, distribution stratigraphique et géographique des mégaspores du Carbonifére et du Permien. In: CONGRÉs InTERnATIONAL DE STRATIGraphie et de GÉOlogie du CARBon, 7, Kiefeld: Compte Rendus 4: 93-102.

PIÉRART P. 1981. Stratigraphical and geographical distribution of Gondwana megaspores. In: INTERNATIONAL Gondwana Symposium, 5, Wellington, 1980. Selected papers and abstracts. Wellington, p. 19-21.

PIÉRART P. 1984. Les mégaspores du Carboniferè et du Gondwana inférieur de l'Afrique et de l'Amerique du Sud. Bull Scea Acad Scea Outre-Mer 28: 155-163.

RAVEN PH, EVERT RF AND EICHHORN SE. 2003. Biology of Plants, $6^{\text {th }}$ ed., New York: W.H. Freeman and Company Worth Publishers, 944 p.

RiCARDI-BRANCO F AND BERNARDES-DE-OLIVEIRA MEC. 2000. Gangamopteris roesleri sp. nov., da Tafoflora eopermiana de Cerquilho (SP), Grupo Tubarão, Bacia do Paraná, Brasil. Rev Univ Guar Geo (special number) p. 44-48.

RICARDI-BRANCO F AND TORRES MR. 2003. Licófitas presentes na Formação Rio Bonito (Permiano Inferior) na área de Figueira, PR. Rev Bras Paleo 6: 19-28.

RICARDI-BRANCO F, BERNARDES-DE-OLIVEIRA ME AND GARCIA MJ. 1999. Novos elementos tafoflorísticos da Formação Assistência, Subgrupo Irati, Grupo Passa Dois, Bacia do Paraná, provenientes de Angatuba (SP), Brasil. Geo 4(6): 85-95.
RicARdi-Branco F, ARAi M AND RÖSler O. 2002. Megaspores from coals of the Triunfo Member, Rio Bonito Formation (Lower Permian), northeastern Paraná State, Brazil. An Acad Bras Cienc 74: 491-503.

Rocha-Campos AC, CAnuto JR and Santos PR. 2000. Late Paleozoic glaciotectonic structures in northern Paraná Basin, Brazil. Sed Geol 130: 131-143.

RoHn R. 1987. A Flora de Glossopteris primitiva de Cerquilho Velho, Formação Tietê, Permiano Inferior, SP, Brasil: Guia da Excursão. Paleobot Latinoamer 8: 25-30.

RoHN R. 1997. Plant megafossil occurrences in the Teresina and Rio do Rasto Formations (Upper Permian of the Paraná Basin) in the state of Santa Catarina, Brazil. Rev Geo II Univ Guar ( $\mathrm{N}^{\circ}$ especial) p. 49-57.

RoHn R AND Lages L. 2000. Lower Permian sphenopsids from Cerquilho, Northeastern Paraná Basin, Brazil. Rev Paleobiol 19: 359-379.

Santos PR, Rocha-CAmpos AC And CANUto JR. 1996. Patterns of Late Paleozoic deglaciation in the Paraná Basin, Brazil. Paleogeogr Paleoclimatol Paleoecol 125: $165-184$.

SouzA PA. 2006. Late Carboniferous palynostratigraphy of the Itararé Subgroup, Northeastern Paraná Basin, Brazil. Rev Palaeobot Palyn 138: 9-29.

Souza PA And Marques-Toigo M. 2003. An overview on the Palynostratigraphy of the Upper Paleozoic strata of the Brazilian Paraná Basin. Rev Mus Arg Cienc Nat 5: 205-214.

Souza PA, Amaral PGC ANd Bernardes-De-OliveIRA MEC. 2006. A Late Carboniferous palynoflora from the Itararé Subgroup (Paraná Basin) in Campinas, São Paulo State, Brazil. Rev Micropaleont 49: 105-115.

Stewart WN ANd Rothwell GW. 1993. Paleobotany and the evolution of plants. Cambridge University Press. Cambridge, $521 \mathrm{p}$.

Surange KR. 1966. Indian fossil Pteridophytes. Council of Scientific and Industrial research. New Delhi, 216 p.

TAYLOR TN AND TAYLOR EL. 1993. The biology and evolution of fossil plants, $1^{\text {st }}$ ed., Nova Jersey: Prentice-Hall, $982 \mathrm{p}$. 